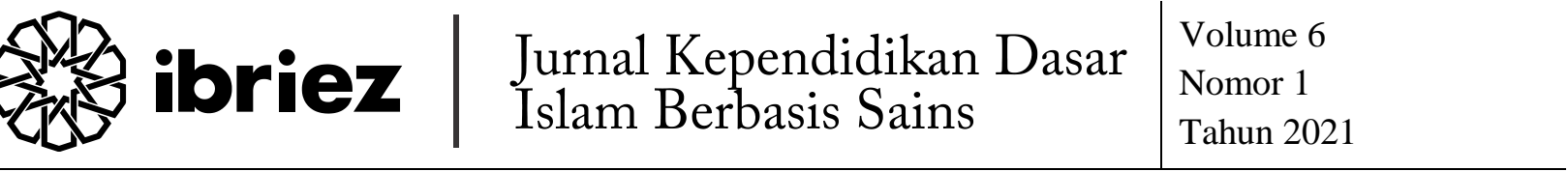

\title{
Hubungan Pendidikan Karakter dengan Coping stress pada Mahasiswa PGSD saat Pembelajaran Daring di Masa Pandemi Covid-19
}

\author{
Frans Aditia Wiguna \\ Universitas Nusantara PGRI Kediri \\ frans@unpkediri.ac.id
}

\begin{abstract}
Abstrak
Penelitian ini membahas hubungan antara pendidikan karakter dengan coping stress pada mahasiswa FKIP Program studi PGSD di Universitas Nusantara PGRI Kediri dalam menghadapi masalah pada saat pembelajaran daring di masa pandemi Covid-19. Hal ini dilatarbelakangi karena dalam kondisi seperti ini banyak mahasiswa yang merasakan kejenuhan dan menyebabkan stres. Salah satu penyebabnya adalah kurang optimalnya pemberian materi yang disampaikan. Untuk mencapai tujuan tersebut, peneliti menggunakan teknik kuantitatif dengan menggunakan jenis penelitian korelasional yaitu penelitian yang bertujuan untuk menemukan ada tidaknya hubungan serta berarti atau tidaknya hubungan tersebut. Selanjutnya data-data dianalisis menggunakan teknik produk moment. Hasil penelitian ini menunjukkan nilai signifikasi 0,002 dengan nilai skor signifikansi kurang dari 0,05 $(<0,05)$ yang digunakan sebagai ketetapan, yang berati jika $\mathrm{F}$ hitung $<\mathrm{F}$ tabel maka $\mathrm{H}_{0}$ diterima, dan jika $\mathrm{F}$ hitung $>\mathrm{F}$ tabel maka $\mathrm{H}_{0}$ ditolak. yang menunjukkan ada hubungan yang sangat signifikan coping stress terhadap pendidikan karakter. Nilai koefisisen regresi variabel coping stress berdasarkan hasil perhitungan dari SPSS versi 21,0 adalah sebesar 0,301 bernilai positif, sehingga dapat dikatakan ada pengaruh positif yang sangat signifikan coping stress terhadap pendidikan karakter. Pengaruh positif dalam penelitian ini menunjukkan bahwa semakin tinggi coping stress seorang mahasiswa maka pendidikan karakter juga semakin tinggi. Sebaliknya, jika semakin rendah coping stress seorang mahasiwa maka pendidikan karakter seorang mahasiswa juga akan semakin rendah.
\end{abstract}

Kata Kunci: Pendidikan Karakter, Coping stress, Pembelajaran Daing, Pandemi Covid-19

\begin{abstract}
The discussion of this study is to determine the extent of the relationship between character education and stress coping among FKIP students PGSD study program at Nusantara University PGRI Kediri in facing problems during online learning during the Covid-19 pandemic, because of the many conditions like this. Many students feel boredom and cause stress, one of the causes is the lack of optimal delivery of the material presented. To achieve this goal, researchers used quantitative techniques using correlational research, namely research that aims to find out whether there is a relationship or whether or not it is a relationship. Furthermore, the data will be analyzed using the product moment technique. Based on the results of research that has been carried out by researchers through the stages of quantitative research, it was found that a significance value of 0.002 with a significance score of less than $0.05(<0.05)$ was used as a determination, which means that if Fcount <Ftable then $\mathrm{HO}$ is accepted, and if Fcount> Ftable then HO is rejected. which shows there is a very significant correlation Coping stress to Character Education. The regression coefficient value of the Coping stress variable based on the calculation results of SPSS version 21.0 is 0.301, which is positive, so it can be said that there is a very significant positive influence. Coping stress on Character Education. The
\end{abstract}


positive influence in this study shows that the higher the Coping stress of a student, the higher the Character Education. Conversely, if the lower the Coping stress of a student, the Character Education of a student will also be lower. A maximum 200 word abstract in English in italics with Cambria 11 point. Abstract should be clear, descriptive, and should provide a brief overview of the problem studied.

Keywords : Character Education, Stress Coping

\section{A. PENDAHULUAN}

Pendidikan di Indonesia saat ini sedang dihadapkan kepada situasi yang kurang menguntungkan. Bukan terletak pada kurikulumnya, namun pada kondisi dan situasi yang luar biasa berdampak pada aspek pendidikan bangsa. Pendidikan sangat berpengaruh sekali terhadap perkembangan bangsa. Akan tetapi kita tidak pernah bisa melihat dan meramalkan bagaimana kondisi pendidikan di bangsa kita esok hari. Seperti yang sedang kita alami saat ini, kondisi pandemi Covid-19 mengakibatkan perubahan yang sangat luar biasa pada bidang pendidikan. Keluh kesah dari semua pihak seakan-akan sama. Hal ini dikarenakan terdapat satu permasalahan dalam pelaksanaannya di lapangan. Dalam pembelajaran daring ini belum ada proses pembelajaran yang distandarkan untuk mencapai pembelajaran yang diinginkan. Pembelajaran daring menggunakan berbagai aplikasi media yang sudah tersedia. Namun penggunaanya tidak serentak sesuai dengan jenjangnya. Berbagai jenjang juga bermacam-macam aplikasi yang digunakannya sesuai dengan arahan dari pendidik/guru. Pendidikan yang berkaitan dengan kognitif sangat mudah sekali disampaikan oleh guru. Guru dapat menggunakan segala macam media pembelajaran baik video ataupun audio melalui daring. Akan tetapi pada kenyataannya guru dan khususnya orang tua masih mengeluhkan dengan karakter anak selama pandemi ini. Alasan utamanya, karena tidak ada lagi sosok pendamping (guru) yang biasanya disegani dan ditiru segala tindak tanduknya oleh anak. Kondisi ini terjadi sejalan dengan semakin tingginya kasus Covid-19, sehingga anak-anak masih harus belajar daring dari rumah yang menyebabkan seseorang menjadi stres dan hal itu juga bisa berpengaruh terhadap perkembangan kognitif yang dimiliki oleh seorang anak atau (dalam kasus ini) mahasiswa.

Salah satu faktor yang dirasakan oleh mahasiswa antara lain adalah yang pertama, tidak optimalnya pemberian materi karena tidak adanya interaksi langsung dengan dosen sehingga materi yang disampaikan terasa kurang bisa dapat dipahami, yang kedua karena kurang bisa memberikan feedback atau tanggapan terhadap materi yang disampaikan dosen, serta terlalu lama untuk melihat gadget dengan durasi yang cukup lama dalam pemberian materi. Hal itulah yang bisa menyebabkan stres yang dialami oleh mahasiswa.

Stres adalah peristiwa-peristiwa fisik maupun juga peristiwa psikologis yang dipersepsikan sebagai ancaman pontensial terhadap gangguan fisik maupun distres secara emosional, singkatnya stress adalah suatu peristiwa atau keadaan yang 
melampaui kemampuan individu untuk mengatasi. ${ }^{1}$ Ditinjau dari latar belakang masalah di atas, maka rumusan masalah pada penelitian ini yaitu, "Bagaimana hubungan antara pendidikan karakter dengan Coping Stres pada mahasiswa FKIP Prodi PGSD di Universitas Nusantara PGRI Kediri dalam menghadapi masalah pembelajaran daring di masa pandemi Covid-19?".

Konsep pendidikan karakter terus berkembang sejalan dengan pemikiranpemikiran baru. Cunningham ${ }^{2}$ dari National-Louis University, USA menyatakan bahwa karakter yang diajarkan di sekolah adalah kepanjangan dari karakter, moral, atau nilai yang ada dan dihargaidi masyarakat, yang dikenal sebagai karakter sosial normatif. Karakter normatif yang meliputi kejujuran, pantang menyerah, kebersahajaan, kewajaran, dan menja-ga emosi, di mana sekolah berperan sebagai agen moral.

Dalam UU Sisdiknas, "Pendidikan merupakan usaha sadar dan terencana untuk mewujudkan suasana belajar dan proses pembelajaran agar peserta didik secara aktif mengembangkan potensi diri agar memiliki kekuatan spiritual, pengendalian diri, kepribadian, kecerdasan, akhlak mulia, serta keterampilan yang diperlukan dirinya, masyarakat, bangsa dan negara." ${ }^{3}$

Sedangkan karakter menurut Kamus Poerwadarminta, mendefinisikan bahwa karakter diartikan sebagai budi pekerti, sifat-sifat kejiwaan, watak, tabiat, atau akhlak yang membedakan antara satu orang dengan orang lain. ${ }^{4}$ Lebih lanjut Thomas Lickona, "karakter adalah A reliable inner disposition to respond to situations in a morally good way. Selanjutnya dia menambahkan, "Character so conceived has threewht interrelated parts: moral knowing, moral feeling, and moral behavior". Menurut Thomas Lickona, karakter mulia (good character) meliputi pengetahuan tentang kebaikan, lalu menimbulkan komitmen (niat) terhadap kebaikan, dan akhirnya benar-benar melakukan kebaikan. Dengan kata lain, acuan dalam karakter ini yaitu kepada serangkaian keterampilan, sikap, perilaku, motivasi, dan pengetahuan." ${ }^{5}$

Sedangkan menurut Imam Al-Ghazali, karakter merupakan spontanitas manusia dalam bersikap, atau melakukan perbuatan yang telah menyatu dalam diri manusia. ${ }^{6}$ Sementara itu Winnie, memahami bahwa istilah karakter memiliki dua pengertian yaitu pertama menunjukkan bagaimana seseorang bertingkah laku dan kedua karakter

\footnotetext{
${ }^{1}$ Ade Ari Isnainy dan Laili Alfita, "Perbedaan Coping Stress Penderita Kanker Ditinjau Dari Jenis Kelamin Di RSUP H. Adam Malik Medan," Universitas Medan Area, Jurnal Diversita, 3, no. 1 (2017): 1-9.

${ }^{2}$ Craig A. Cunningham, Character Education in Public Schools: The Quest for a Suitable Ontology. (Chicago: National- Louis University., 2007), 5.

3 "UNDANG-UNDANG REPUBLIK INDONESIA NOMOR 20 TAHUN 2003 TENTANG SISTEM PENDIDIKAN NASIONAL," 2003.

${ }^{4}$ Abdul Majid dan Dian Andayani, Pendidikan Karakter Perspektif Islam (Bandung: Remaja Rosdakarya, 2012), 11.

${ }^{5}$ Dalmeri, "Pendidikan untuk Pengembangan Karakter (Telaah terhadap Gagasan Thomas Lickona dalam Educating for Character)," Al-Ulum, 14, no. 01 (2014): 271-72.

${ }^{6}$ Heri Gunawan, Pendidikan Karakter: Konsep dan Implementasinya (Bandung: Alfabeta, 2018), 3.
} 
erat kaitannya dengan personality. Seseorang baru disebut orang yang berkarakter apabila tingkah lakunya sesuai dengan kaidah moral. ${ }^{7}$

Lebih lanjut menurut Thomas Lickona, pendidikan karakter adalah pendidikan untuk membentuk kepribadian seseorang melalui pendidikan budi pekerti, yang hasilnya terlihat dalam tindakan nyata seseorang, yaitu tingkah laku baik, menghormati orang lain, kerja keras, jujur, bertanggung jawab dan lain sebagainya. ${ }^{8}$ Hal ini juga dikuatkan oleh Megawangi dalam Kesuma, dkk., pendidikan karakter adalah suatu usaha yang dilakukan untuk mendidik anak-anak agar dapat mengambil keputusan dengan bijak dan mempraktikkannya dalam kehidupan sehari-hari, sehingga dapat memberikan kontribusi positif kepada lingkungannya. ${ }^{9}$

Dari berbagai definisi tersebut dapat disimpulkan bahwa pendidikan karakter merupakan usaha sadar dan terencana untuk menanamkan dan mengembangkan perilaku positif yang sesuai dengan kaidah-kaidah moral. Adapun tujuan pelaksanaan pendidikan karakter adalah untuk membentuk insan menjadi pribadi yang memiliki nilai-nilai utama dalam kehidupan sehari-harinya, misalnya nilai kejujuran, menegakkan keadilan, semangat untuk membantu, kerja keras, pemurah, tanggung jawab, saling menghormati, membela orang yang lemah, sikap ksatria atau teguh dalam memegang amanah. ${ }^{10}$

Coping adalah suatu usaha untuk mengubah kognisi atau tingkah laku secara konstan sebagai usaha untuk mengendalikan tuntutan baik eksternal maupun internal, khususnya yang diperkirakan akan menyita dan melampaui kemampuan seseorang. Selanjutnya dijelaskan bahwa coping berkenaan dengan apa yang dilakukan oleh individu untuk mengatasi situasi yang penuh dengan tekanan atau yang menurut individu secara emosional. Selanjutnya menambahkan juga bahwa cara yang dilakukan oleh individu untuk mengtasi situasi atau problem yang dianggap sebagai tantangan, ketidakadilan ataupun merugikan sebagai ancaman yang disebut dengan istilah coping stres.

Istilah Coping sering disamakan dengan adjusment (penyesuaian diri) dan problem solving (cara memecahkan masalah). Namun sebenarnya coping memiliki makna harfiah pengatasan, penanggulangan, (to cope with = mengatasi menanggulangi). Coping berarti apa saja yang dilakukan oleh individu untuk menguasai sebuah situasi yang dinilai sebagai suatu tantangan, luka, kehilangan, ancaman. Coping lebih mengarah kepada yang orang lakukan untuk mengatasi tuntutan yang penuh tekanan atau yang membangkitkan emosi. ${ }^{11}$

\footnotetext{
${ }^{7}$ Fatchul Mu'in, Pendidikan Karakter: Konstruksi Teoritik dan Praktik (Jogjakarta: Ar-Ruzz Media, 2017), 160.

${ }^{8}$ Heri Gunawan, Pendidikan Karakter: Konsep dan Implementasinya, 23.

${ }^{9}$ Pipit Uliana dan Rr. Nanik Setyowati, "Implementasi Pendidikan Karakter melalui Kultur Sekolah pada Siswa Kelas XI di SMA Negeri 1 Gedangan Sidoarjo"," Kajian Moral dan Kewarganegaraan, 1, no. 1 (2013): 168.

${ }^{10}$ Akhmad Muhaimin Azzet, Urgensi Pendidikan Karakter di Indonesia: Revitalisasi Pendidikan Karakter terhadap Keberhasilan belajar dan Kemajuan Bangsa (Jogjakarta: Ar-Ruzz Media, 2018), 17.

${ }^{11}$ Siswanto, Kesehatan Mental “Konsep, Cakupan dan Perkembangannya” (Yogyakarta: Andi, 2007), 60.
} 
Penggunaan konsep coping sebagai istilah dalam menjelaskan relasi antara tingkah laku dan stres individu dalam menghadapi tekanan. Dengan begitu, coping dipandang sebagai faktor penyeimbang dan usaha mempertahankan penyesuaian selama menghadapi stres. Dengan kata lain coping adalah bagaimana reaksi seorang ketika menghadapi stres atau tekanan. ${ }^{12}$ Coping merupakan upaya yang digunakan untuk mengelola situasi yang membebani, memperluas usaha untuk memecahkan masalah hidup, dan berusaha untuk menguasai atau mengurangi stres. Stres dikenali sebagai interaksi antara kemampuan coping seseorang dengan tuntutan lingkungannya. Stres merupakan proses psikobiologikal (adanya stimulus yang membahayakan fisik dan psikis bersifat mengancam, lalu memunculkan reaksi-reaksi kecemasan). ${ }^{13}$ Stres adalah peristiwa-peristiwa fisik maupun psikologis yang dipersepsikan sebagai ancaman pontensial terhadap gangguan fisik maupun distres secara emosional, singkatnya stres adalah suatu peristiwa atau keadaan yang melampaui kemampuan individu untuk mengatasi. ${ }^{14}$

Randy Prawita Putra dkk, meneliti tentang tujuan memberikan gambaran mengenai startegi coping stres pada remaja korban cyberbullying, dalam jurnal tersebut didapati hasil bahwa semua subjek menggunakan dua jenis strategi coping stres yakni problem focused coping (strategi yang diarahkan pada masalah) dan emotional focused coping (cara yang digunakan untuk mengatur respon emosional terhadap stres). ${ }^{15}$ Tujuan penelitian ini adalah untuk mencari hubungan yang terjadi antara pendidikan karakter dengan coping stres yang dimiliki oleh mahasiswa FKIP Prodi PGSD di Universitas Nusantara PGRI Kediri melalui daring.

\section{B. Metode}

Penelitian ini menggunakan pendekatan penelitian kuantitatif yang menekankan analisisinya pada data-data numerikal (angka) yang diolah dengan metode statitika. ${ }^{16}$ Penelitian ini menggunakan jenis penelitian korelasional yaitu penelitian yang bertujuan untuk menemukan ada tidaknya hubungan serta berarti atau tidaknya hubungan tersebut. ${ }^{17}$ Penelitian ini menggunakan metode survei lapangan. Menurut Kerlinger penelitian survei adalah penelitian yang dilakukan pada populasi besar maupun kecil, tetapi data yang dipelajari adalah data yang diambil dari sampel populasi tersebut, untuk menemukan kejadian-kejadian relatif, distributi, dan hubungan-hubungan antar variabel sosiologis maupun psikologis. ${ }^{18}$

\footnotetext{
12 Siswanto, 61.

${ }^{13}$ Kartika Sari D., Kesehatan Mental (Semarang: Lestari Media Kreatif, 2012), 106.

${ }^{14}$ Ade Ari Isnainy dan Laili Alfita, "Perbedaan Coping Stress Penderita Kanker Ditinjau Dari Jenis Kelamin Di RSUP H. Adam Malik Medan."

15 Randy Prawita P. dan Atika Dian A, "Gambaran Strategi Coping Stress pada Remaja Korban Cyberbullying"," Jurnal Psikologi Klinis dan Kesehatan Mental, 5, no. 1 (2016): 1-10.

${ }^{16}$ Saifudin Azwar, Metode Penelitian (Jakarta: Pustaka Pelajar, 2004), 5.

17 Suharsimi Arikuntoro, Prosedur Penelitian Suatu Pendekatan Praktek (Jakarta: Rineka Cipta, 2018), 251.

${ }^{18}$ Sugiyono, Metode Penelitian Manajemen (Bandung: Alfabeta, 2014), 80.
} 


\section{Hasil dan Pembahasan}

Pengujian validitas dan reliabilitas data menggunakan uji coba dan berdasarkan software SPSS 21 for windows. Prosedur uji validitas yang dilakukan dalam penelitian ini adalah validitas isi yang berupa professional judgement yang artinya dalam pengevaluasian item penilaian dikonfirmasikan pada ahli di bidangnya. Dengan tujuan item skala memang mendukung konstrak teoritik yang diukur dan item tersebut dinyatakan sebagai item yang layak mendukung validitas isi angket. Berikut ini adalah uraian data dari hasil penelitian yang telah peneliti lakukan:

\section{Uji validitas}

1. Uji Validitas Instrumen Pendidikan Karakter dengan uji coba

Tabel 1. Blue Print Skala Pendidikan Karakter

\begin{tabular}{|l|c|c|c|c|}
\hline \multirow{2}{*}{ Indikator } & \multicolumn{2}{|c|}{ Item Awal } & \multicolumn{2}{c|}{ Item yang tidak Gugur/ dipakai } \\
\cline { 2 - 5 } & Favorable & Unfavorable & Favorable & Unfavorable \\
\hline Religious & $1,3,5,7$ & $2,4,6$ & 1,5 & $2,4,6$ \\
\hline Jujur & $8,10,12$ & 9,11 & - & 9,11 \\
\hline Toleransi & $13,15,17$ & 14,16 & 13,15 & 16 \\
\hline Disiplin & $18,20,22$ & 19,21 & 18,22 & 21 \\
\hline Kerja Keras & $23,25,27,29,31$ & $24,26,28,30$ & 27,31 & - \\
\hline Kreatif & $32,34,36$ & 33,35 & $32,34,36$ & 33,35 \\
\hline Mandiri & $37,39,41,43,45$, & $38,40,42,44,46$ & $37,39,43,45$, & $38,40,42$, \\
& 47 & 49,51 & - & 49,51 \\
\hline Demokratis & $48,50,52$ & 54 & 53,55 & - \\
\hline $\begin{array}{l}\text { Rasa Ingin } \\
\text { Tahu }\end{array}$ & 53,55 & & & 57,59 \\
\hline $\begin{array}{l}\text { Semangat } \\
\text { kebangsaan }\end{array}$ & $56,58,60$ & 57,59 & & $\mathbf{1 6}$ \\
\hline \multicolumn{1}{|c|}{ Total } & $\mathbf{3 5}$ & $\mathbf{2 5}$ & $\mathbf{1 9}$ & \\
\hline
\end{tabular}

Dari tabel tersebut diketahui bahwa berdasar uji korelasi item pada 60 item pernyataan dari variabel Adversity Quotient didapatkan Untuk item dari Adversity Quotient terdapat 35 item yang tidak gugur dan 25 item yang dinyatakan gugur item yang valid.

2. Uji Validitas Instrumen Coping stress dengan uji coba

Tabel 2. Blue Print Skala Coping stress

\begin{tabular}{|l|c|c|c|c|}
\hline \multirow{2}{*}{ Indikator } & \multicolumn{2}{|c|}{ Item Awal } & \multicolumn{2}{c|}{ Item yang tidak Gugur/ dipakai } \\
\cline { 2 - 5 } & Favorable & Unfavorable & Favorable & Unfavorable \\
\hline Konfrontasi & 1,3 & 2 & - & 2 \\
\hline $\begin{array}{l}\text { Mencari } \\
\begin{array}{l}\text { Dukungan } \\
\text { Sosial }\end{array}\end{array}$ & $4,6,8,10$ & $5,7,9$ & 6,8 & 5,7 \\
\hline $\begin{array}{l}\text { Merencakan } \\
\text { Pemecahan } \\
\text { masalah }\end{array}$ & 11,13 & 12 & 11 & 12 \\
\hline
\end{tabular}




\begin{tabular}{|l|c|c|c|c|}
\hline Kontrol Diri & $\begin{array}{c}14,16,18,20, \\
22\end{array}$ & $15,17,19,21$ & 20,22 & 19,21 \\
\hline Distancing & 23,25 & 24,26 & 23,25 & 24,26 \\
\hline Escape & $27,29,31$ & $28,30,32$ & 27,31 & 30,32 \\
\hline Acceptance & $33,35,37,39$ & $34,36,38$ & $33,35,37$ & 34,38 \\
\hline $\begin{array}{l}\text { Positive } \\
\text { reapprasial }\end{array}$ & $40,42,44,46$ & $41,43,45$ & 44 & $41,43,45$, \\
\hline \multicolumn{1}{|c|}{ Total } & $\mathbf{2 6}$ & $\mathbf{2 0}$ & $\mathbf{1 3}$ & $\mathbf{1 5}$ \\
\hline
\end{tabular}

Dari tabel tersebut diketahui bahwa berdasar uji korelasi item pada 46 item pernyataan dari variabel Coping Stress didapatkan 18 item gugur dinyatakan dihapus dan 28 item dinyatakan tidak gugur.

\section{Uji reliabilitas}

1. Uji reliabilitas Pendidikan Karakter

Tabel 3. Hasil Uji Skala Pendidikan Karakter

\begin{tabular}{|c|c|c|}
\hline Variable & Cronbach's Alpha & N of Items \\
\hline Pendidikan Karakter &, 835 & 60 \\
\hline
\end{tabular}

Dari tabel di atas dapat disimpulkan skala pendidikan karakter adalah reliabel, dimana Cronbach Alpha 0,835 yang berarti reliabilitas sangat tinggi.

2. Uji reliabilitas Coping stress

Tabel 4. Hasil Uji Skala Coping stress

\begin{tabular}{|l|c|c|}
\hline \multicolumn{1}{|c|}{ Variable } & Cronbach's Alpha & N of Items \\
\hline Coping stress & 0,719 & 46 \\
\hline
\end{tabular}

Dari tabel di atas maka dapat disimpulkan skala Coping Stress adalah reliabel, dimana Cronbach Alpha 0,719 yang berarti reliabilitas tinggi.

\section{Uji Normalitas}

Tabel 5. One-Sample Kolmogorov-Smirnov Test

\begin{tabular}{|c|c|c|c|}
\hline \multicolumn{2}{|c|}{} & Coping_stress & Pendidikan_Karakter \\
\hline \multirow{2}{*}{ Normal Parameters ${ }^{a, b}$} & Mean & 100 & 100 \\
\cline { 2 - 4 } & Std. Deviation & 133,08 & 173,27 \\
\hline \multirow{3}{*}{ Most Extreme Differences } & Absolute & 8,435 & 12,642 \\
\cline { 2 - 4 } & Positive &, 080 &, 117 \\
\cline { 2 - 4 } & Negative & -052 &, 117 \\
\hline Kolmogorov-Smirnov Z & &,- 080 &,- 093 \\
\hline Asymp. Sig. (2-tailed) & &, 800 & 1,170 \\
\hline
\end{tabular}

a. Test distribution is Normal.

b. Calculated from data.

Dari data di atas menunjukkan variabel Coping Stress dengan nilai sig 0,544 dan variabel Pendidikan Karakter dengan nilai sig 0,130. Keduanya menunjukkan nilai 
sig lebih dari 0,05 $(>0,05)$ sehingga dapat diketahui bahwa semua data berdistribusi normal. ${ }^{19}$

\section{Uji Linearitas}

Tabel 7. ANOVA

\begin{tabular}{|c|c|c|c|c|c|c|c|}
\hline & & & $\begin{array}{l}\text { Sum of } \\
\text { squares }\end{array}$ & $d f$ & $\begin{array}{l}\text { Mean } \\
\text { Square }\end{array}$ & $F$ & Sig \\
\hline \multirow{5}{*}{$\begin{array}{l}\text { Pendidika } \\
\mathrm{n} \\
\text { Karakter* } \\
\text { Coping_Str } \\
\text { ess }\end{array}$} & \multirow{3}{*}{$\begin{array}{l}\text { Betwee } \\
n \\
\text { Groups }\end{array}$} & (Combined) & 5192,636 & 31 & 167,504 & 1,072 & ,396 \\
\hline & & Linearity & 1436,494 & 1 & 1436,494 & 9,190 & 003 \\
\hline & & $\begin{array}{l}\text { Deviation From } \\
\text { Linearity }\end{array}$ & 3756,142 & 30 & 125,205 & 801 & ,746 \\
\hline & \multicolumn{2}{|c|}{ Within Groups } & 10629,074 & 68 & 156,310 & & \\
\hline & \multicolumn{2}{|l|}{ Total } & 15821,710 & 99 & & & \\
\hline
\end{tabular}

Data di atas menunjukkan nilai signifikasin 0,746 yang berarti nilai signifikasi lebih dari 0,05 (0,746 > 0,05), maka dapat diketahui bahwa variabel Coping stress dengan Pendidikan Karakter adalah linear.

\section{Uji hipotesis}

Tabel 7. Correlations

\begin{tabular}{|l|l|l|l|}
\hline \multicolumn{2}{|l|}{} & Pendidikan_Karakter & \multicolumn{1}{c|}{ Coping_stress } \\
\hline \multirow{4}{*}{ Pendidikan_Karakter } & Pearson Correlation & 1 &, $301^{* *}$ \\
\cline { 2 - 4 } & Sig. (2-tailed) & &, 002 \\
\cline { 2 - 4 } & $N$ & 100 & 100 \\
\hline \multirow{3}{*}{ Coping_stress } & Pearson Correlation &, $301^{* *}$ & 1 \\
\cline { 2 - 4 } & Sig. (2-tailed) &, 002 & \\
\cline { 2 - 4 } & $N$ & 100 & 100 \\
\hline
\end{tabular}

Berdasarkan hasil perhitungan korelasi melalui SPSS 21 menunjukkan angka korelasi Pearson antara coping stres (X) dan Karakter Pendidikan (Y) sebesar 0,003. Dengan skor signifikan 0,002 yang lebih kecil < 0,05. Oleh karena itu H0 ditolak dan Ha diterima. ${ }^{20}$ Karena skor korelasinya positif (+), maka korelasinya bersifat positif. Sehingga dapat disimpulkan ada hubungan positif antara Pendidikan Karakter dengan coping stress pada FKIP Prodi PGSD di Universitas Nusantara PGRI Kediri melalui perkuliahan daring. Yang menunjukkan arti bahwa semakin tinggi coping stress, maka semakin tinggi Pendidikan Karater pada mahasiswa FKIP Prodi PGSD di Universitas Nusantara PGRI Kediri melalui perkuliahan daring.

${ }^{19}$ Wiratna Sujarwati, Belajar Mudah SPSS untuk Penelitian Mahasiswa dan Umum (Yogyakarta: Global Media Informasi, 2018), 48.

${ }^{20}$ Wiratna Sujarwati, Belajar Mudah SPSS untuk Penelitian Mahasiswa dan Umum. 


\section{Tingkat Pendidikan Karakter}

Tabel 8. Descriptive Statistics

\begin{tabular}{|l|l|l|l|l|l|l|}
\hline & \multicolumn{1}{|c|}{$N$} & Minimum & Maximum & \multicolumn{2}{|c|}{ Mean } & $\begin{array}{c}\text { Std. } \\
\text { Deviation }\end{array}$ \\
\cline { 2 - 7 } & Statistic & Statistic & Statistic & Statistic & $\begin{array}{l}\text { Std. } \\
\text { Error }\end{array}$ & Statistic \\
\hline Pendidikan_Karakter & 100 & 148 & 201 & 173,27 & 1,264 & 12,642 \\
\hline
\end{tabular}

Dari tabel di atas diperoleh deskripsi data kemandirian dengan nilai rata-rata (mean) sebesar 173,27 dan standart deviasinya sebesar 12,642. Dari hasil tersebut selanjutnya nilai dari mean dan standar deviasi dijadikan patokan untuk membagi tingkatan pendidikan karakter kedalam lima tingkatan yaitu sangat tinggi, tinggi, sedang, rendah dan sangat rendah.

Tabel 9. Tabel Pedoman Nilai Konversi Pendidikan Karakter

\begin{tabular}{|c|c|c|}
\hline Rumus & Perhitungan & Skor \\
\hline $\mathrm{M}+(1,5$. SD) & $173,27+(1,5.12,642)$ & 192,23 \\
\hline $\mathrm{M}+(0,5$. SD) & $173,27+(0,5.12,642)$ & 179,59 \\
\hline $\mathrm{M}-(0,5$. SD) & $173,27-(0,5.12,642)$ & 166,95 \\
\hline $\mathrm{M}-(1,5$. SD) & $173,27-(1,5.12,642)$ & 154,31 \\
\hline
\end{tabular}

Dari tabel di atas, setelah dimasukkan ke dalam rumus menunjukkan skor tertinggi dari hasil penjumlahan skala adalah 192,23 dan terendah adalah 154,31.

Tabel 10. Kategorisasi skor Pendidikan Karakter pada Mahasiswa PGSD

\begin{tabular}{|c|c|c|}
\hline $\begin{array}{c}\text { No } \\
\text { Subjek }\end{array}$ & Skor Subjek & Kategori \\
\hline 1 & 195 & Sangat Tinggi \\
\hline 2 & 160 & Rendah \\
\hline 3 & 188 & Tinggi \\
\hline 4 & 171 & Sedang \\
\hline 5 & 168 & Sedang \\
\hline 6 & 173 & Sedang \\
\hline 7 & 162 & Rendah \\
\hline 8 & 174 & Sedang \\
\hline 9 & 173 & Sedang \\
\hline 10 & 167 & Sedang \\
\hline 11 & 191 & Tinggi \\
\hline 12 & 160 & Rendah \\
\hline 13 & 151 & Sangat Rendah \\
\hline 14 & 189 & Tinggi \\
\hline 15 & 150 & Sangat Rendah \\
\hline 16 & 161 & Rendah \\
\hline 17 & 184 & Tinggi \\
\hline 18 & 163 & Rendah \\
\hline 19 & 171 & Sedang \\
\hline 20 & 177 & Sedang \\
\hline
\end{tabular}

\begin{tabular}{|c|c|c|}
\hline $\begin{array}{c}\text { No } \\
\text { Subjek }\end{array}$ & Skor Subjek & Kategori \\
\hline 21 & 191 & Tinggi \\
\hline 22 & 174 & Sedang \\
\hline 23 & 173 & Sedang \\
\hline 24 & 190 & Tinggi \\
\hline 25 & 186 & Tinggi \\
\hline 26 & 170 & Sedang \\
\hline 27 & 171 & Sedang \\
\hline 28 & 164 & Rendah \\
\hline 29 & 200 & Sangat Tinggi \\
\hline 30 & 187 & Tinggi \\
\hline 31 & 171 & Sedang \\
\hline 32 & 164 & Rendah \\
\hline 33 & 201 & Sangat Tinggi \\
\hline 34 & 187 & Tinggi \\
\hline 35 & 171 & Sedang \\
\hline 36 & 172 & Sedang \\
\hline 37 & 171 & Sedang \\
\hline 38 & 162 & Rendah \\
\hline 39 & 174 & Sedang \\
\hline 40 & 193 & Sangat Tinggi \\
\hline
\end{tabular}




\begin{tabular}{|c|c|c|c|c|c|}
\hline $\begin{array}{c}\text { No } \\
\text { Subjek }\end{array}$ & Skor Subjek & Kategori & $\begin{array}{c}\text { No } \\
\text { Subjek }\end{array}$ & Skor Subjek & Kategori \\
\hline 41 & 158 & Rendah & 71 & 156 & Rendah \\
\hline 42 & 188 & Tinggi & 72 & 185 & Tinggi \\
\hline 43 & 169 & Sedang & 73 & 168 & Sedang \\
\hline 44 & 167 & Sedang & 74 & 168 & Sedang \\
\hline 45 & 172 & Sedang & 75 & 171 & Sedang \\
\hline 46 & 161 & Rendah & 76 & 160 & Rendah \\
\hline 47 & 174 & Sedang & 77 & 170 & Sedang \\
\hline 48 & 172 & Sedang & 78 & 168 & Sedang \\
\hline 49 & 166 & Rendah & 79 & 166 & Rendah \\
\hline 50 & 189 & Tinggi & 80 & 189 & Tinggi \\
\hline 51 & 159 & Rendah & 81 & 160 & Rendah \\
\hline 52 & 148 & Sangat Rendah & 82 & 151 & Sangat Rendah \\
\hline 53 & 187 & Tinggi & 83 & 187 & Tinggi \\
\hline 54 & 148 & Sangat Rendah & 84 & 149 & Sangat Rendah \\
\hline 55 & 160 & Rendah & 85 & 158 & Rendah \\
\hline 56 & 182 & Tinggi & 86 & 175 & Sedang \\
\hline 57 & 164 & Rendah & 87 & 164 & Rendah \\
\hline 58 & 170 & Sedang & 88 & 170 & Sedang \\
\hline 59 & 176 & Sedang & 89 & 177 & Sedang \\
\hline 60 & 191 & Tinggi & 90 & 186 & Tinggi \\
\hline 61 & 172 & Sedang & 91 & 171 & Sedang \\
\hline 62 & 175 & Sedang & 92 & 172 & Sedang \\
\hline 63 & 190 & Tinggi & 93 & 188 & Tinggi \\
\hline 64 & 185 & Tinggi & 94 & 179 & Sedang \\
\hline 65 & 169 & Sedang & 95 & 170 & Sedang \\
\hline 66 & 171 & Sedang & 96 & 169 & Sedang \\
\hline 67 & 164 & Rendah & 97 & 162 & Rendah \\
\hline 68 & 198 & Sangat Tinggi & 98 & 198 & Sangat Tinggi \\
\hline 69 & 185 & Tinggi & 99 & 181 & Tinggi \\
\hline 70 & 192 & Tinggi & 100 & 157 & Rendah \\
\hline
\end{tabular}

Dari hasil tersebut variabel Pendidikan Karakter dikategorisasikan ke dalam lima tingkat hasilnya adalah sebagai berikut:

Tabel 11. Distribusi Nilai Variabel Pendidikan Karakter

\begin{tabular}{|c|c|c|c|}
\hline Interval skor & Kategori & Frekuensi & Persentase \\
\hline Skor $>192,23$ & Sangat Tinggi & 6 & $6 \%$ \\
\hline $179,59<$ Skor $<192,23$ & Tinggi & 24 & $24 \%$ \\
\hline $166,95<$ Skor $<179,59$ & Sedang & 41 & $41 \%$ \\
\hline $154,31<$ Skor $<166,95$ & Rendah & 23 & $23 \%$ \\
\hline Skor $\leq 154,31$ & Sangat Rendah & 6 & $6 \%$ \\
\hline
\end{tabular}




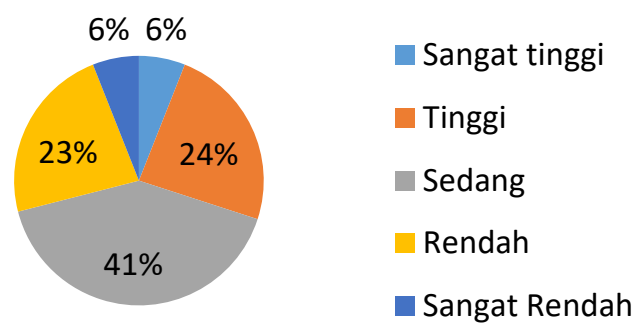

Diagram 1. Persentase Distribusi Nilai Variabel Pendidikan Karakter

Dari tabel 11 dan diagram 1 dapat dinyatakan bahwa pendidikan karakter pada mahasiswa FKIP Prodi PGSD di Universitas Nusantara PGRI Kediri masuk dalam kategori sedang dengan 41 responden atau sebesar $41 \%$ karena hasil tersebut mayoritas tingkat Pendidikan Karakter berada pada tingkat sedang.

\section{Tingkat Coping stress}

Tabel 12. Descriptive Statistics

\begin{tabular}{|c|c|c|c|c|c|c|}
\hline & N & Minimum & Maximum & \multicolumn{2}{|c|}{ Mean } & $\begin{array}{c}\text { Std. } \\
\text { Deviation }\end{array}$ \\
\cline { 2 - 7 } & Statistic & Statistic & Statistic & Statistic & Std. Error & Statistic \\
\hline $\begin{array}{c}\text { Coping } \\
\text { stres }\end{array}$ & 100 & 113 & 151 & 133,08 &, 843 & 8,435 \\
\hline
\end{tabular}

Dari tabel di atas diperoleh deskripsi data kemandirian dengan nilai rata-rata (mean) sebesar 133,08 dan standart deviasinya sebesar 8,435. Dari hasil tersebut selanjutnya nilai dari mean dan standart deviasi dijadikan patokan untuk membagi tingkatan Coping Stress ke dalam lima tingkatan yaitu sangat tinggi, tinggi, sedang, rendah dan sangat rendah.

Tabel 13. Tabel Pedoman Nilai Konversi Coping Stress

\begin{tabular}{|c|c|c|}
\hline Rumus & Perhitungan & Skor \\
\hline $\mathrm{M}+(1,5$. SD) & $133,08+(1,5.8,435)$ & 145,73 \\
\hline $\mathrm{M}+(0,5$. SD) & $133,08+(0,5.8,435)$ & 137,30 \\
\hline $\mathrm{M}-(0,5$. SD) & $133,08-(0,5.8,435)$ & 128.86 \\
\hline $\mathrm{M}-(1,5$. SD) & $133,08-(1,5.8,435)$ & 120,43 \\
\hline
\end{tabular}

Dari tabel di atas, setelah dimasukkan ke dalam rumus menunjukkan skor tertinggi dari hasil penjumlahan skala adalah 145,73 dan terendah adalah 120,43.

Tabel 14. Kategorisasi skor Coping Stress Mahasiswa PGSD

\begin{tabular}{|c|c|c|}
\hline $\begin{array}{c}\text { No } \\
\text { Subjek }\end{array}$ & $\begin{array}{c}\text { Skor } \\
\text { Subjek }\end{array}$ & Kategori \\
\hline 1 & 151 & Sangat Tinggi \\
\hline 2 & 129 & Sedang \\
\hline 3 & 144 & Tinggi \\
\hline 4 & 140 & Tinggi \\
\hline 5 & 132 & Sedang \\
\hline 6 & 132 & Sedang \\
\hline 7 & 136 & Sedang \\
\hline 8 & 128 & Rendah \\
\hline 9 & 133 & Sedang \\
\hline
\end{tabular}

\begin{tabular}{|c|c|c|}
\hline $\begin{array}{c}\text { No } \\
\text { Subjek }\end{array}$ & $\begin{array}{c}\text { Skor } \\
\text { Subjek }\end{array}$ & Kategori \\
\hline 10 & 130 & Sedang \\
\hline 11 & 136 & Sedang \\
\hline 12 & 113 & Sangat Rendah \\
\hline 13 & 127 & Rendah \\
\hline 14 & 140 & Tinggi \\
\hline 15 & 124 & Rendah \\
\hline 16 & 116 & Sangat Rendah \\
\hline 17 & 141 & Tinggi \\
\hline 18 & 129 & Sedang \\
\hline
\end{tabular}




\begin{tabular}{|c|c|c|}
\hline $\begin{array}{c}\text { No } \\
\text { Subjek }\end{array}$ & $\begin{array}{c}\text { Skor } \\
\text { Subjek }\end{array}$ & Kategori \\
\hline 19 & 135 & Sedang \\
\hline 20 & 135 & Sedang \\
\hline 21 & 151 & Sangat Tinggi \\
\hline 22 & 139 & Tinggi \\
\hline 23 & 120 & Sangat Rendah \\
\hline 24 & 142 & Tinggi \\
\hline 25 & 143 & Tinggi \\
\hline 26 & 129 & Sedang \\
\hline 27 & 137 & Sedang \\
\hline 28 & 130 & Sedang \\
\hline 29 & 143 & Tinggi \\
\hline 30 & 124 & Rendah \\
\hline 31 & 136 & Sedang \\
\hline 32 & 139 & Tinggi \\
\hline 33 & 139 & Tinggi \\
\hline 34 & 124 & Rendah \\
\hline 35 & 136 & Sedang \\
\hline 36 & 132 & Sedang \\
\hline 37 & 142 & Tinggi \\
\hline 38 & 125 & Rendah \\
\hline 39 & 135 & Sedang \\
\hline 40 & 139 & Tinggi \\
\hline 41 & 144 & Tinggi \\
\hline 42 & 128 & Rendah \\
\hline 43 & 136 & Sedang \\
\hline 44 & 132 & Sedang \\
\hline 45 & 142 & Tinggi \\
\hline 46 & 124 & Rendah \\
\hline 47 & 137 & Sedang \\
\hline 48 & 129 & Sedang \\
\hline 49 & 146 & Sangat Tinggi \\
\hline 50 & 141 & Tinggi \\
\hline 51 & 133 & Sedang \\
\hline 52 & 133 & Sedang \\
\hline 53 & 137 & Sedang \\
\hline 54 & 130 & Sedang \\
\hline 55 & 135 & Sedang \\
\hline 56 & 131 & Sedang \\
\hline 57 & 135 & Sedang \\
\hline 58 & 114 & Sangat Rendah \\
\hline 59 & 127 & Rendah \\
\hline
\end{tabular}

\begin{tabular}{|c|c|c|}
\hline $\begin{array}{c}\text { No } \\
\text { Subjek }\end{array}$ & $\begin{array}{c}\text { Skor } \\
\text { Subjek }\end{array}$ & Kategori \\
\hline 60 & 138 & Sedang \\
\hline 61 & 124 & Rendah \\
\hline 62 & 117 & Sangat Rendah \\
\hline 63 & 142 & Tinggi \\
\hline 64 & 129 & Sedang \\
\hline 65 & 135 & Sedang \\
\hline 66 & 149 & Sangat Tinggi \\
\hline 67 & 131 & Sedang \\
\hline 68 & 144 & Tinggi \\
\hline 69 & 140 & Tinggi \\
\hline 70 & 130 & Sedang \\
\hline 71 & 132 & Sedang \\
\hline 72 & 136 & Sedang \\
\hline 73 & 130 & Sedang \\
\hline 74 & 134 & Sedang \\
\hline 75 & 129 & Sedang \\
\hline 76 & 138 & Sedang \\
\hline 77 & 115 & Sangat Rendah \\
\hline 78 & 127 & Rendah \\
\hline 79 & 138 & Tinggi \\
\hline 80 & 123 & Rendah \\
\hline 81 & 117 & Sangat Rendah \\
\hline 82 & 140 & Tinggi \\
\hline 83 & 126 & Rendah \\
\hline 84 & 134 & Sedang \\
\hline 85 & 115 & Sangat Rendah \\
\hline 86 & 142 & Tinggi \\
\hline 87 & 127 & Rendah \\
\hline 88 & 133 & Sedang \\
\hline 89 & 150 & Sangat Tinggi \\
\hline 90 & 134 & Sedang \\
\hline 91 & 136 & Sedang \\
\hline 92 & 123 & Rendah \\
\hline 93 & 136 & Sedang \\
\hline 94 & 130 & Sedang \\
\hline 95 & 141 & Tinggi \\
\hline 96 & 124 & Rendah \\
\hline 97 & 135 & Sedang \\
\hline 98 & 137 & Sedang \\
\hline 99 & 115 & Sangat Rendah \\
\hline 100 & 142 & Tinggi \\
\hline
\end{tabular}


Dari hasil tersebut variabel coping stress dikategorisasikan ke dalam lima tingkat hasilnya adalah sebagai berikut:

Tabel 15. Distribusi Nilai Variabel Coping Stress

\begin{tabular}{|c|c|c|c|}
\hline Interval skor & Kategori & Frekuensi & Persentase \\
\hline Skor $>145,73$ & Sangat Tinggi & 5 & $5 \%$ \\
\hline $137,30<$ Skor $<145,73$ & Tinggi & 25 & $25 \%$ \\
\hline $128.86<$ Skor $<137,30$ & Sedang & 45 & $45 \%$ \\
\hline $120,43<$ Skor $<128.86$ & Rendah & 16 & $16 \%$ \\
\hline Skor $\leq 120,43$ & Sangat Rendah & 9 & $9 \%$ \\
\hline
\end{tabular}

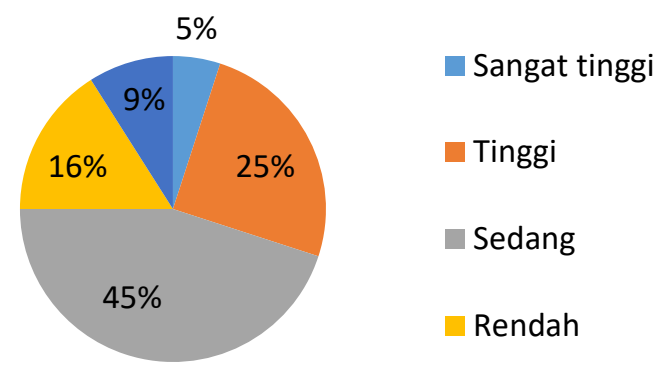

\section{Diagram 2. Persentase Distribusi Nilai Variabel Coping Stress}

Dari tabel 15 dan diagram 2 dapat dinyatakan bahwa Coping Stress pada mahasiswa FKIP Prodi PGSD di Universitas Nusantara PGRI Kediri masuk dalam kategori sedang dengan 45 responden atau sebesar $45 \%$ karena hasil tersebut mayoritas tingkat Coping Stress berada pada tingkat sedang.

Berdasarkan hasil penelitian yang telah dilakukan oleh peneliti melalui tahaptahap penelitian kuantitatif, ditemukan nilai signifikasi 0,002 dengan nilai skor signifikansi kurang dari 0,05 $(<0,05)$ yang digunakan sebagai ketetapan, yang berati jika $\mathrm{F}_{\text {hitung }}<\mathrm{F}_{\text {tabel }}$ maka $\mathrm{H}_{0}$ diterima, dan jika $\mathrm{F}_{\text {hitung }}>\mathrm{F}_{\text {tabel }}$ maka $\mathrm{H}_{0}$ ditolak. yang menunjukkan ada hubungan yang sangat signifikan Coping Stress terhadap pendidikan karakter. Nilai koefisisen regresi variabel Coping Stress berdasarkan hasil perhitungan dari SPSS versi 21,0 adalah sebesar 0,301 bernilai positif, sehingga dapat dikatakan ada pengaru posisitif yang sangat signifikan Coping Stress terhadap pendidikan karakter. Pengaruh positif dalam penelitian ini menunjukkan bahwa semakin tinggi Coping Stress seorang Mahasiswa maka Pendidikan karakter juga semakin tinggi. Sebaliknya, jika semakin rendah Coping Stress mahasiswa maka pendidikan karakter seorang mahasiswa juga akan semakin rendah.

\section{PENUTUP}

Besar tingkat Pendidikan karakter pada mahasiswa FKIP Prodi PGSD di Universitas Nusantara PGRI Kediri melalui perkuliahan daring masuk dalam kategori sedang dengan berdasarkan kategori skala pendidikan karakter menujukkan bahwa 
prosentase $41 \%$ dari jumlah populasi atau 41 responden dari 100 responden yang menjadi populasi.

Hal tersebut menunjukkan bahwa mayoritas mahasiswa FKIP Prodi PGSD di Universitas Nusantara PGRI Kediri melalui perkuliahan daring yang memenuhi aspekaspek pendidikan karakter adalah masuk dalam kategori sedang. Besar tingkat Coping Stress pada mahasiswa FKIP Prodi PGSD di Universitas Nusantara PGRI Kediri melalui perkuliahan daring masuk dalam kategori sedang dengan persentase $45 \%$ dari jumlah populasi atau 45 responden dari 100 responden yang menjadi populasi. Hal tersebut menunjukkan bahwa mayoritas dari mahasiswa FKIP Prodi PGSD di Universitas Nusantara PGRI Kediri melalui perkuliahan daring yang memenuhi aspek-aspek coping stress yang diungkapkan oleh Smet yaitu aspek problem focused coping atau strategi yang digunakan kepada suatu masalah yang sudah dialami atau yang sudah terjadi dan aspek emotion focused coping atau cara yang digunakan untuk mengatur respon emosional terhadap stres adalah masuk dalam kategori sedang. Pada hasil perhitungan hipotesis terdapat skor 0.002 yang bersifat positif, oleh karena itu sehingga dapat disimpulkan ada hubungan positif antara coping stress dengan pendidikan karakter pada mahasiswa FKIP Prodi PGSD di Universitas Nusantara PGRI Kediri. Yang menunjukkan arti bahwa semakin tinggi Coping Stress, maka semakin tinggi pendidikan karakter pada mahasiswa FKIP Prodi PGSD di Universitas Nusantara PGRI Kediri.

\section{E. Daftar Pustaka}

Abdul Majid dan Dian Andayani. Pendidikan Karakter Perspektif Islam. Bandung: Remaja Rosdakarya, 2012.

Ade Ari Isnainy dan Laili Alfita. "Perbedaan Coping Stress Penderita Kanker Ditinjau Dari Jenis Kelamin Di RSUP H. Adam Malik Medan.” Universitas Medan Area, Jurnal Diversita, 3, no. 1 (2017): 1-9.

Akhmad Muhaimin Azzet. Urgensi Pendidikan Karakter di Indonesia: Revitalisasi Pendidikan Karakter terhadap Keberhasilan belajar dan Kemajuan Bangsa. Jogjakarta: Ar-Ruzz Media, 2018.

Craig A. Cunningham. Character Education in Public Schools: The Quest for a Suitable Ontology. Chicago: National- Louis University., 2007.

Dalmeri. "Pendidikan untuk Pengembangan Karakter (Telaah terhadap Gagasan Thomas Lickona dalam Educating for Character)," Al-Ulum, 14, no. 01 (2014): 269-88.

Fatchul Mu'in. Pendidikan Karakter: Konstruksi Teoritik dan Praktik. Jogjakarta: Ar-Ruzz Media, 2017.

Heri Gunawan. Pendidikan Karakter: Konsep dan Implementasinya. Bandung: Alfabeta, 2018.

Kartika Sari D. Kesehatan Mental. Semarang: Lestari Media Kreatif, 2012.

Pipit Uliana dan Rr. Nanik Setyowati. "Implementasi Pendidikan Karakter melalui Kultur Sekolah pada Siswa Kelas XI di SMA Negeri 1 Gedangan Sidoarjo"," Kajian Moral dan Kewarganegaraan, 1, no. 1 (2013): 165-79. 
Randy Prawita P. dan Atika Dian A. "Gambaran Strategi Coping Stress pada Remaja Korban Cyberbullying"," Jurnal Psikologi Klinis dan Kesehatan Mental, 5, no. 1 (2016): 1-10.

Saifudin Azwar. Metode Penelitian. Jakarta: Pustaka Pelajar, 2004.

Siswanto. Kesehatan Mental "Konsep, Cakupan dan Perkembangannya." Yogyakarta: Andi, 2007.

Sugiyono. Metode Penelitian Manajemen. Bandung: Alfabeta, 2014.

Suharsimi Arikuntoro. Prosedur Penelitian Suatu Pendekatan Praktek. Jakarta: Rineka Cipta, 2018.

“UNDANG-UNDANG REPUBLIK INDONESIA NOMOR 20 TAHUN 2003 TENTANG SISTEM PENDIDIKAN NASIONAL," 2003.

Wiratna Sujarwati. Belajar Mudah SPSS untuk Penelitian Mahasiswa dan Umum. Yogyakarta: Global Media Informasi, 2018. 